\title{
Modelling Pathways for Outbreaks in Field Occupational Epidemiology
}

\author{
Jerónimo Maquedaํㅜ, Agustín Silva², Rosa-Ana Cortés ${ }^{3}$, María-Fe Gamo ${ }^{3}$ \\ ${ }^{1}$ Health Promotion and Occupational Epidemiology Department, National Institute of Safety and Health at Work, Madrid, Spain \\ ${ }^{2}$ Faculty of Medicine and Health Sciences, Alcalá de Henares University, Madrid, Spain \\ ${ }^{3}$ National School of Occupational Medicine, Institute of Health Carlos III, Madrid, Spain \\ Email: jeronimo.maqueda@insst.mites.gob.es
}

How to cite this paper: Maqueda, J., Silva, A., Cortés, R.-A. and Gamo, M.-F. (2021) Modelling Pathways for Outbreaks in Field Occupational Epidemiology. Open Journal of Preventive Medicine, 11, 91-112. https://doi.org/10.4236/ojpm.2021.114009

Received: January 8, 2021

Accepted: April 4, 2021

Published: April 7, 2021

Copyright (c) 2021 by author(s) and Scientific Research Publishing Inc. This work is licensed under the Creative Commons Attribution International License (CC BY 4.0).

http://creativecommons.org/licenses/by/4.0/

\section{(c) (i) Open Access}

\begin{abstract}
Background: The investigation of an occupational outbreak, once the index case has been identified, triggers a stress situation to epidemiologists. Modelling occupational outbreaks will be useful to guide the field investigation. Objective: To identify standard pathways for occupational epidemic outbreaks. Methods: In-depth critical appraisal of 57 occupational outbreaks. Standard pathways of occupational outbreaks were identified by analysing the similarity between out-breaks. The model's accuracy and homogeneity were established through Fisher's exact test and the Kappa Index. Results: The analysis allowed synthesizing the occupational outbreaks variability in 4 pathways. $92.98 \%$ of the analysed outbreaks could be allocated to one of those 4 types. The theoretical patterns showed a good adjustment with the analysed out-breaks: Type I (Kappa $=0.94-0.60)$, Type II $($ Kappa $=1.00)$, Type III $($ Kappa $=1.00-0.68)$ and Type IV $($ Kappa $=0.94-0.87)$. The probability of a given outbreak fitting with its three components in any of the theoretical pathways was 0.83 . Conclusions: The incorporation of those pathways to the field occupational epidemiology will allow: 1) to provide early guidance to epidemiological, clinical and environmental studies focused on specific hypothesis of causality; 2) to anticipate preventive measures; 3 ) to contribute to an earlier and more efficient outbreak resolution.
\end{abstract}

\section{Keywords}

Occupational Outbreak, Occupational Diseases, Working Exposure, Field Epidemiology

\section{Introduction}

Working environment as part of the disease aetiological complex was already 
evidenced by the empirical observations of Bernardino Ramazzini (1633-1714) reported in "De Morbis Artificium Diatriba" [1].

Ramazzini's contribution to the medical reasoning was to include the study of the occupational activity and work-related exposure in the disease interpretation and the explanation of its causal complex.

The workplace environment is included at the core of the public health concept as a determinant of collective health. In this sense, health and wellbeing related to specific working conditions are incorporated into the morbidity profile of different territories and population groups.

Marisa Corfiati et al. [2], evidence how the location of mesothelioma clusters in the Italian municipalities is associated with the economic development of the asbestos industry in those territories.

The main epidemiological intelligence agencies: Europe-CDC [3], USA-CDC [4], Australia NHNRC [5] systematise the outbreak investigation in a series of steps, which includes, these components: Person, time and place and the corroboration of causal hypotheses by statistical methods. In spite of accepting this system, difficulties are found for its application in the field of occupational epidemiology. Jorma Rantanen [6] at the International Conference "New Epidemics in Occupational Health", held in Helsinki in 1994, warns about the difficulties in identifying occupational clusters and applies the term "silent epidemics" when referring to them.

Schulte et al. [7] add the difficulty of applying statistical methods in the study of occupational clusters. After analysing 61 clusters of occupational cancer investigated by the US National Institute of Occupational Safety and Health (NIOSH), Schulte proposes that to investigate occupational cancer clusters less "quantitative epidemiology" and more "interpretative epidemiology" is needed.

Just like Ramazzini proposed to add to the three Hippocratic questions a new one: "What is your occupation?" [8], it is necessary to add to the three conventional components in field epidemiology a new one, a "technological component": Person-Time-Place-Technology.

The importance of studying this technological component in occupational epidemiology is demonstrated by Moya et al. [9] when investigating an outbreak of 22 cases of organising pneumonia. The analysis of the "technological component" allowed us to conclude that all cases were workers of the textile industry, 20 cases from only 2 companies $(\mathrm{RR}=24.3 ; 95 \% \mathrm{CI}=5.7-104.4)$ and all of them were involved in textile printing by spraying procedures.

The work process mapping and its analysis have a special interest for field occupational epidemiology since it allows identifying the risk exposure at the exact point where it occurs and whether it affects one or several tasks and, therefore, one or several workers' groups.

The importance of overlapping the "technological component" with "time" and "place" is evidenced in the outbreak reported by Zimmermann et al. [10].

In that outbreak, Zimmermann analyses the "technological component" by mapping the cases through the working process, which we can call a "technolo- 
gical map of cases", showing that its occurrence was sequential across the working process, and showed a concordance in time with the path of the raw material.

Therefore, considering that working processes can be standardised and that cases have a limited distribution at the plant, we can formulate the hypothesis that occupational out-breaks follow some patterns. This would allow to synthesise its variability in a limited number of Standard Occupational Outbreak Pathways and to formulate the main objective of characterizing them according to the following components: Technological linkage, place at plant, and potential causal agent.

The matter concerning the model's adequacy may be analysed by means of the following specific goals: 1) to identify the fit between theoretical models and real outbreaks; 2) to check the internal homogeneity of each pathway; and 3) to identify the prevalence and the probability of the different epidemiological pathways.

\section{Material and Methods}

In-depth critical appraisal of occupational outbreaks, published between January 2000 and May 2014, in journals indexed in PubMed. The collection to be studied was recovered by means of an advanced search builder including the following terms: Outbreak OR epidemic AND occupational asthma/Outbreak OR epidemic AND occupational dermatitis/Outbreak OR epidemic AND occupational cancer/Outbreak OR epidemic AND occupational exposure.

Articles that met all the inclusion criteria were included for analysis, and articles that met at least one of the exclusion criteria were excluded (Table 1).

In order to identify the specific characteristics of occupational outbreaks and to establish the elements to summarise their variability, a sample of the total collection was analysed. The sample was selected systematically according to the order of the full text review, and the sampling quota was higher than $50 \%$ of the

Table 1. Eligibility criteria.

- Original papers
- English or Spanish language
- Published between January 2000 and May 2014
- Sick population were workers
- Occutbreaks started in a working environment
(e.g., severe acute respiratory syndrome, avian influenza) in order to
avoid that an excess of publications in this health alerts could modify
the profile of outbreaks in working environments.
Public health or environmental outbreaks (mediated by vectors,
water, foods, etc.) as they are far from the subject of the study due to
their epidemiological characteristics.
Outbreaks of person/person transmission, since their occupational
origin may be uncertain.
Outbreaks of zoonosis by contact with live animals not arising from
professional activities: wild or domestic animals, etc.


total collection.

In order to extract information, a synthesis matrix was designed and relevant epidemiological and scientific information was collected.

The similarities between outbreaks were analysed for the following epidemiological parameters: 1) Links between cases and working process; 2) Spatial distribution of cases; 3) Agents or risk exposure potentially involved.

The standard pathways of occupational outbreak (SPOO) were formulated based on the similarities of those three epidemiological parameters.

The internal homogeneity of each defined SPOO was analysed with Fisher's exact test.

The fit between components (technological linkage, spatial distribution and agent involved) for each SPOO was analysed by the Kappa index.

The probability analysis for the occurrence of each SPOO was carried out by analysing the combined probabilities of the three components taken one by one, on the basis of one sequence: Spatial distribution -> Technological relationship -> Agent involved.

The variability of presentation typologies was calculated through the number of variations with replacement of four elements (types of behaviour), taken in three-by-three elements (analysed components).

\section{Results}

The results obtained in the search process are shown in (Figure 1). A total of 57
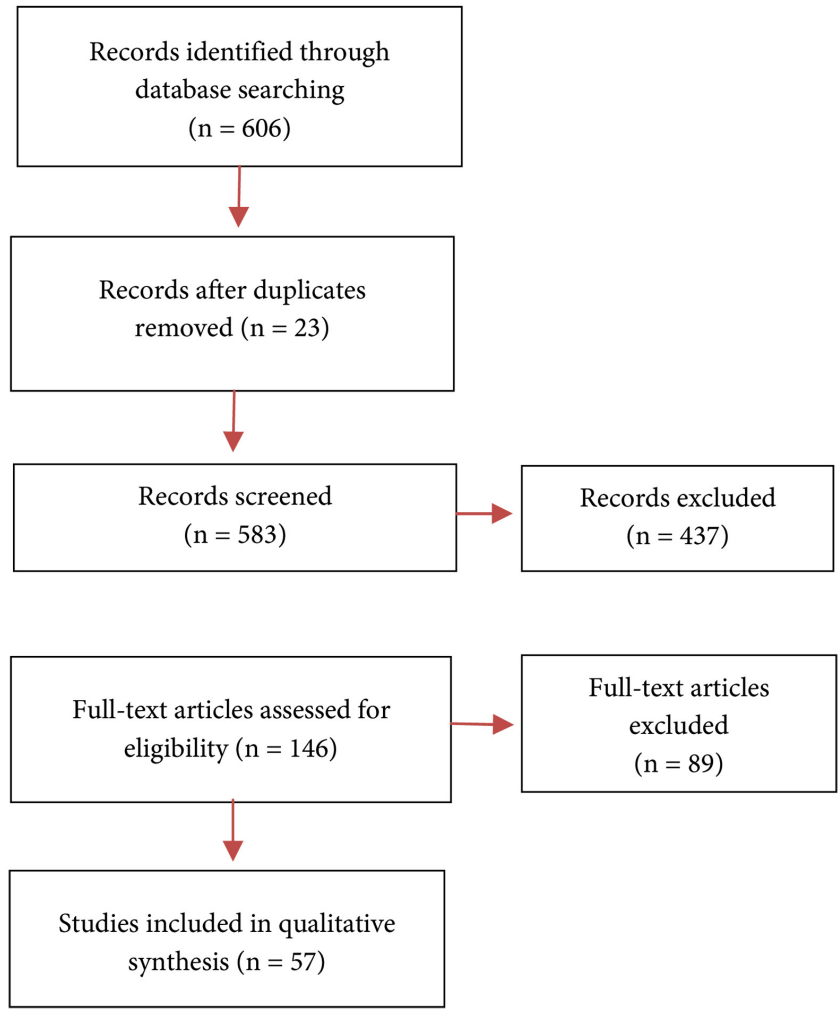

Figure 1. References reviewed and selected for study. 
articles were recovered, and a sample of 33 articles was selected to be analysed in the process of characterisation of the standard pathways of occupational outbreak.

Out of the 33 outbreaks analysed (Table 2), 13 reported that the outbreak occurred among workers performing a specific task of the production process [11]-[23]. No cases were reported of workers involved in other activities, except additional cases that occurred nearby as a result of an environmental spread of the contaminant [14] [17] [18].

In this group of 13 outbreaks, there was not always information concerning all the aspects related to occupational exposure, preventive measures or working conditions, but in these outbreaks there was a concurrence of causes regarding: the expo-sure to conventional substances or products handled while performing a specific task [14] [16] [17] [18] [19] [21] [22] [23], innovation processes [11] [12] [13] [15], poor working conditions [11] [12] [13] [17] [18] [21] [22] [23], unusual operations within the working process [14], improperly performed processes [15] [18] or ancillary contaminated products [19].

Out of these 13 outbreaks, 6 reported on the spatial distribution of cases. All of them showed that the outbreak was limited to the plant area where the task related to exposure to the causal agent took place [16] [17] [18] [20] [21] [23].

In other 8 outbreaks (Table 3 ), out of the 33 analysed, the cluster occurred among workers who performed different tasks within the working process but technologically linked by a common exposure to products or substances with a cross-sectional use [24]-[31]. Cases were limited to these tasks-areas, except additional cases nearby as a result of an environmental spread of contaminants [24] [25] [28] [30].

The causal agents described in the analysis were related to substances or ancillary products used to operate machinery [24] [25] [27] [31], personal protective equipment or work clothes [26] [29], innovative processes [27] or poor working conditions [28].

Out of these 8 outbreaks, 6 reported the spatial distribution of cases, which involved several plant areas where different tasks were performed, but shared the exposure to the causal agent [24] [26] [27] [28] [30] [31].

In 8 of the 33 analysed outbreaks (Table 4), the cluster occurred with workers in-volved in different tasks within the working process in a sequenced way. Cases were linked to the route of the contaminant through the production stages [32]-[39], with additional cases reported nearby as a result of an environmental spread of the contaminant [33] [37].

In 5 of these 8 outbreaks, authors reported the spatial distribution of cases [33] [34] [35] [36] [38], showing a distribution involving several areas of the plant where consecutive tasks of the working process were performed.

The causal agents described are related to: innovative processes [32], raw material additives 36, raw material deterioration [33] [34] [35] [39], concurring or not with poor working conditions [37]. 
Table 2. Synthesis of outbreak information regarding to occupational relationships (I).

\begin{tabular}{|c|c|c|c|c|c|c|c|}
\hline \multicolumn{8}{|c|}{ Information regarding to occupational relationships (I) } \\
\hline Ref. & Title & $\begin{array}{l}\text { Task performed } \\
\text { (relationship } \\
\text { between cases ) }\end{array}$ & $\begin{array}{l}\text { Agent/risk } \\
\text { exposure }\end{array}$ & $\begin{array}{l}\text { Environmental } \\
\text { spread }\end{array}$ & $\begin{array}{c}\text { Exposure } \\
\text { circumstances }\end{array}$ & Concurrent facts & $\begin{array}{c}\text { Cases } \\
\text { location }\end{array}$ \\
\hline 11 & $\begin{array}{l}\text { Contact dermatitis from } \\
\text { methylisothiazolinone } \\
\text { in a paint factory }\end{array}$ & $\begin{array}{l}\text { Pouring additives } \\
\text { into a mixing } \\
\text { container in the } \\
\text { production of } \\
\text { water-based } \\
\text { paints }\end{array}$ & Methylisothiazolinone & - & $\begin{array}{l}\text { Innovation } \\
\text { Processes (new } \\
\text { preservative) }\end{array}$ & $\begin{array}{l}\text { Poor working } \\
\text { conditions }\end{array}$ & - \\
\hline 12 & $\begin{array}{l}\text { An epidemic of } \\
\text { occupational contact } \\
\text { dermatitis from an } \\
\text { acrylic glue }\end{array}$ & $\begin{array}{l}\text { Examine coils for } \\
\text { defects and } \\
\text { manual } \\
\text { disassemble the } \\
\text { defective ones }\end{array}$ & Acrylic glue & - & $\begin{array}{l}\text { Innovation } \\
\text { Processes (new } \\
\text { glue) }\end{array}$ & $\begin{array}{l}\text { Poor working } \\
\text { conditions }\end{array}$ & - \\
\hline 13 & $\begin{array}{l}\text { Concomitant contact } \\
\text { allergy to the resins, } \\
\text { reactive diluents and } \\
\text { hardener of a } \\
\text { bisphenol A/F-based } \\
\text { epoxy resin in subway } \\
\text { construction workers }\end{array}$ & $\begin{array}{l}\text { Insertion of iron } \\
\text { bars into concrete } \\
\text { walls in the } \\
\text { construction of } \\
\text { new subway } \\
\text { stations }\end{array}$ & $\begin{array}{l}\text { Bisphenol A/F-based } \\
\text { epoxy resin system }\end{array}$ & - & $\begin{array}{l}\text { Innovation } \\
\text { Processes (new } \\
\text { resin) }\end{array}$ & $\begin{array}{l}\text { Poor working } \\
\text { conditions }\end{array}$ & - \\
\hline 14 & $\begin{array}{l}\text { Allergic contact } \\
\text { dermatitis from } \\
\text { dicyclohexylmethane- } \\
4,4 \text { '-diisocyanate }\end{array}$ & $\begin{array}{l}\text { Cleaning a } \\
\text { centrifuge after a } \\
\text { massive } \\
\text { contamination } \\
\text { of DMDI }\end{array}$ & $\begin{array}{l}\text { Isocyanate } \\
\text { dicyclohexylme- } \\
\text { thane- } 4,4^{\prime} \text {-diisocyanate } \\
\text { (DMDI), }\end{array}$ & $\begin{array}{l}\text { Additional cases } \\
\text { due to an } \\
\text { environmental } \\
\text { spread of the } \\
\text { agent }\end{array}$ & $\begin{array}{l}\text { Conventional } \\
\text { products in } \\
\text { the task } \\
\text { performance }\end{array}$ & $\begin{array}{l}\text { Non-routine } \\
\text { operations }\end{array}$ & - \\
\hline 15 & $\begin{array}{l}\text { Occupational allergic } \\
\text { contact dermatitis in } \\
\text { a company } \\
\text { manufacturing } \\
\text { boards coated with } \\
\text { isocyanate lacquer }\end{array}$ & $\begin{array}{l}\text { Operators by the } \\
\text { machine lacquer }\end{array}$ & $\begin{array}{l}\text { Ddiphenylmethane-4,40 } \\
\text {-diisocyanate (MDI) }\end{array}$ & - & $\begin{array}{l}\text { Innovation } \\
\text { Processes (new } \\
\text { lacquer) }\end{array}$ & $\begin{array}{l}\text { Processes } \\
\text { developed } \\
\text { improperly }\end{array}$ & - \\
\hline 16 & $\begin{array}{l}\text { New-onset asthma } \\
\text { associated with } \\
\text { exposure to } \\
\text { 3-amino-5-mercapto-1,2,4 } \\
\text {-triazole }\end{array}$ & $\begin{array}{l}\text { Charge AMT into } \\
\text { production vessel }\end{array}$ & $\begin{array}{l}\text { 3-amino-5-mercapto- } \\
\text { 1,2,4-triazole (AMT) }\end{array}$ & $\begin{array}{l}\text { Environmental } \\
\text { spread. No } \\
\text { additional cases }\end{array}$ & $\begin{array}{l}\text { Conventional } \\
\text { products in task } \\
\text { performance }\end{array}$ & - & $\begin{array}{l}\text { Task siting } \\
\text { place }\end{array}$ \\
\hline 17 & $\begin{array}{l}\text { Epidemiologic } \\
\text { investigation of } \\
\text { immune-mediated } \\
\text { polyradiculoneuropathy } \\
\text { among abattoir workers } \\
\text { exposed to porcine brain. }\end{array}$ & $\begin{array}{l}\text { Removing porcine } \\
\text { brains with } \\
\text { compressed air }\end{array}$ & Aerosol nervous tissue & $\begin{array}{l}\text { Additional cases } \\
\text { due to an } \\
\text { environmental } \\
\text { spread of the } \\
\text { agent }\end{array}$ & $\begin{array}{l}\text { Conventional } \\
\text { products in task } \\
\text { performance }\end{array}$ & $\begin{array}{l}\text { Poor working } \\
\text { conditions }\end{array}$ & $\begin{array}{l}\text { Task siting } \\
\text { place }\end{array}$ \\
\hline 18 & $\begin{array}{l}\text { Trichloroethylene: } \\
\text { Parkinsonism and } \\
\text { complex } 1 \text { mitochondrial } \\
\text { neurotoxicity }\end{array}$ & $\begin{array}{l}\text { Degreasing } \\
\text { metal parts }\end{array}$ & Trichloroethylene & $\begin{array}{l}\text { Additional cases } \\
\text { due to an } \\
\text { environmental } \\
\text { spread of the } \\
\text { agent }\end{array}$ & $\begin{array}{l}\text { Conventional } \\
\text { products in task } \\
\text { performance }\end{array}$ & $\begin{array}{l}\text { Poor working } \\
\text { conditions } \\
\text { Processes } \\
\text { developed } \\
\text { improperly }\end{array}$ & $\begin{array}{l}\text { Task siting } \\
\text { place }\end{array}$ \\
\hline
\end{tabular}


industrial outbreak amo: an rubber molding workers.

Cold blast furnace

20 syndrome: a new source of toxic inhalation by nitrogen oxides

Epidemiologic

21 investigation of respiratory morbidity at a nylon flock plant

An epidemic of silicosis

22 among former denim sandblasters

23

Group A streptococcal skin infection outbreak in an abattoir: lessons for prevention
Operators of steam presses to add adhesive in rubber strips for automobile Thre (through manual handling) to an adhesive containing dinitrobenzene bumper

Recovery process of a "cold blast furnace"

Exposure to nitrogen oxides at high pressure and temperature

Flocking tasks and cleaning residual flock

Nylon fibers and dust

Denim sandblasting tasks Silica

Gutting (evisceration) tasks
Lamb carcasses

contaminated by streptococcus Group A

Conventional products in task Contaminated performance

Maintenance

tasks

Conventional products in task performance

Poor working conditions

Task siting place

\section{Conventional} products in task Poor working performance

Conventional products in task Poor working performance
Task siting place

(-) Non-reported.

Table 3. Synthesis of outbreak information regarding to occupational relationships (II).

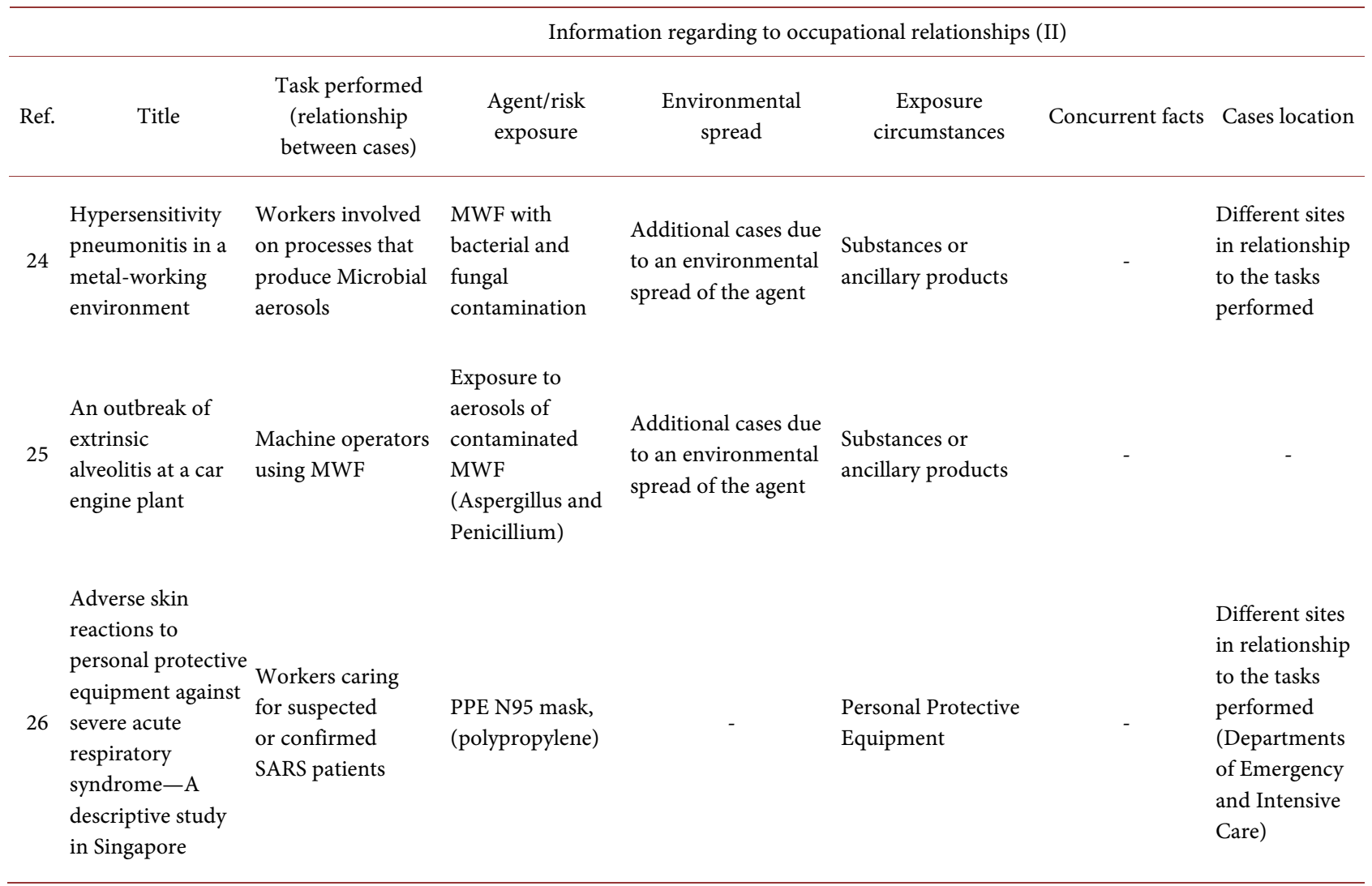




\section{Continued}

\begin{tabular}{|c|c|c|c|c|c|c|c|}
\hline 27 & $\begin{array}{l}\text { Hypersensitivity } \\
\text { pneumonitis due } \\
\text { to metal working } \\
\text { fluids: Sporadic or } \\
\text { under reported? }\end{array}$ & $\begin{array}{l}\text { Machine operators } \\
\text { using MWF in } \\
\text { three different } \\
\text { automobile part } \\
\text { manufacturing } \\
\text { plants }\end{array}$ & $\begin{array}{l}\text { MWF } \\
\text { contaminated } \\
\text { with mycobacteria }\end{array}$ & - & $\begin{array}{l}\text { Substances or } \\
\text { ancillary products }\end{array}$ & $\begin{array}{l}\text { Innovation } \\
\text { Processes }\end{array}$ & $\begin{array}{l}\text { Different sites } \\
\text { in relationship } \\
\text { to the tasks } \\
\text { performed }\end{array}$ \\
\hline 28 & $\begin{array}{l}\text { Aerosol mapping } \\
\text { of a facility with } \\
\text { multiple cases of } \\
\text { hypersensitivity } \\
\text { pneumonitis: } \\
\text { demonstration of } \\
\text { mist reduction and } \\
\text { a possible } \\
\text { dose/response } \\
\text { relationship }\end{array}$ & $\begin{array}{l}\text { Workers involved } \\
\text { in different tasks, } \\
\text { sharing the } \\
\text { exposure to MWF } \\
\text { in machining } \\
\text { processes. }\end{array}$ & MWF mists & $\begin{array}{l}\text { Environmental } \\
\text { spread. No } \\
\text { additional cases }\end{array}$ & - & $\begin{array}{l}\text { Poor working } \\
\text { conditions }\end{array}$ & $\begin{array}{l}\text { Different sites } \\
\text { in relationship } \\
\text { to the tasks } \\
\text { performed }\end{array}$ \\
\hline 29 & $\begin{array}{l}\text { An outbreak of } \\
\text { occupational } \\
\text { textile dye } \\
\text { dermatitis from } \\
\text { disperse blue } 106\end{array}$ & $\begin{array}{l}\text { Workers wearing a } \\
\text { working uniform }\end{array}$ & $\begin{array}{l}\text { Dye disperse } \\
\text { blue } 106 \text { and } 124\end{array}$ & - & Working uniform & - & - \\
\hline 30 & $\begin{array}{l}\text { Clinical } \\
\text { investigation of an } \\
\text { outbreak of } \\
\text { alveolitis and } \\
\text { asthma in a car } \\
\text { engine } \\
\text { manufacturing } \\
\text { plant }\end{array}$ & $\begin{array}{l}\text { Workers involved } \\
\text { in the machining } \\
\text { or washing of metal } \\
\text { pieces operations }\end{array}$ & $\begin{array}{l}\text { Exposure to } \\
\text { aerosols of } \\
\text { contaminated } \\
\text { MWF } \\
\text { (Acinetobacter } \\
\text { spp and } \\
\text { Ochrobacter } \\
\text { anthropic) }\end{array}$ & $\begin{array}{l}\text { Additional cases due } \\
\text { to an environmental } \\
\text { spread of the agent }\end{array}$ & - & - & $\begin{array}{l}\text { Different sites } \\
\text { in relationship } \\
\text { to the tasks } \\
\text { performed }\end{array}$ \\
\hline 31 & $\begin{array}{l}\text { An outbreak of } \\
\text { occupational } \\
\text { asthma due to } \\
\text { chromium and } \\
\text { cobalt }\end{array}$ & $\begin{array}{l}\text { Workers involved } \\
\text { in milling, turning } \\
\text { and grinding } \\
\text { metal pieces }\end{array}$ & $\begin{array}{l}\text { MWF } \\
\text { contaminated } \\
\text { with chromium } \\
\text { and cobalt }\end{array}$ & - & $\begin{array}{l}\text { Substances or } \\
\text { ancillary products }\end{array}$ & - & $\begin{array}{l}\text { Different sites } \\
\text { in relationship } \\
\text { to tasks } \\
\text { performed }\end{array}$ \\
\hline
\end{tabular}

(-) Non-reported (MWF) = Metal Working Fluid.

Finally, in a group of 4 of the 33 outbreaks analysed (Table 5), the main determinant of risk exposure showed an environmental nature due to contamination of the working environment. This environmental exposure prevailed over the exposure linked to the handling of both equipment and substances within the working process [40] [41] [42] [43].

In these outbreaks, cases were located in the contaminated places. One of the outbreaks occurred while working in a natural environment [41] and the remainder, in places located inside the plant [40] [42] [43].

In 2 of these outbreaks the exposure to physical contaminants was identified due to the proximity of radiant facilities [42] [43]. In one case, the workplace contamination had a chemical origin, as a result of usual operations in the working process [41]; another outbreak was due to contaminated walls [40]. As regards the concurrent facts in 2 of the outbreaks, poor maintenance jobs or 
Table 4. Synthesis of outbreak information regarding to occupational relationships (III).

\begin{tabular}{|c|c|c|c|c|c|c|c|}
\hline \multicolumn{8}{|c|}{ Information regarding to occupational relationships (III) } \\
\hline Ref. & Title & $\begin{array}{l}\text { Task performed } \\
\text { (relationship } \\
\text { between cases) }\end{array}$ & $\begin{array}{l}\text { Agent/risk } \\
\text { exposure }\end{array}$ & $\begin{array}{c}\text { Environmental } \\
\text { spread }\end{array}$ & $\begin{array}{c}\text { Exposure } \\
\text { circumstances }\end{array}$ & $\begin{array}{l}\text { Concurrent } \\
\text { facts }\end{array}$ & $\begin{array}{l}\text { Cases } \\
\text { location }\end{array}$ \\
\hline 32 & $\begin{array}{l}\text { An outbreak of asthma } \\
\text { in a modern detergent } \\
\text { factory }\end{array}$ & $\begin{array}{l}\text { Workers involved } \\
\text { in packing tasks, } \\
\text { production and } \\
\text { distribution }\end{array}$ & $\begin{array}{l}\text { Encapsulated } \\
\text { enzymes } \\
\text { (proteases, } \\
\text { amylase and } \\
\text { cellulase) }\end{array}$ & - & - & $\begin{array}{l}\text { Innovation } \\
\text { processes }\end{array}$ & - \\
\hline 33 & $\begin{array}{l}\text { Organic dust toxic } \\
\text { syndrome at a grass seed } \\
\text { plant caused by exposure } \\
\text { to high concentrations } \\
\text { of bio-aerosols }\end{array}$ & $\begin{array}{l}\text { Reception and } \\
\text { storage of seeds, } \\
\text { handling of cleaning } \\
\text { machines, working } \\
\text { in proximity. }\end{array}$ & $\begin{array}{l}\text { Grass seeds } \\
\text { contaminated } \\
\text { with endotoxins } \\
\text { and microbial } \\
\text { content }\end{array}$ & $\begin{array}{l}\text { Additional cases } \\
\text { due to an } \\
\text { environmental } \\
\text { spread of the } \\
\text { agent }\end{array}$ & $\begin{array}{l}\text { Raw material } \\
\text { contaminated }\end{array}$ & - & $\begin{array}{l}\text { Consecutive } \\
\text { workplaces in } \\
\text { relationship with } \\
\text { the working } \\
\text { process }\end{array}$ \\
\hline 34 & $\begin{array}{l}\text { Cluster of presumed } \\
\text { organic dust toxic syn- } \\
\text { drome cases among } \\
\text { urban landscape } \\
\text { workers-Colorado, } \\
2007\end{array}$ & $\begin{array}{l}\text { Mulch loading } \\
\text { and unloading }\end{array}$ & $\begin{array}{l}\text { Mulch dust } \\
\text { contaminated by } \\
\text { fungi, bacteria } \\
\text { and endotoxins }\end{array}$ & - & $\begin{array}{l}\text { Raw material } \\
\text { contaminated }\end{array}$ & - & $\begin{array}{l}\text { Consecutive } \\
\text { workplaces in } \\
\text { relationship with } \\
\text { the working } \\
\text { process }\end{array}$ \\
\hline 35 & $\begin{array}{l}\text { A cluster of } \\
\text { leptospirosis } \\
\text { among abattoir } \\
\text { workers }\end{array}$ & $\begin{array}{l}\text { Workers involved in } \\
\text { several tasks in the } \\
\text { abattoir process }\end{array}$ & $\begin{array}{l}\text { Exposure to urine } \\
\text { of Infected cattle }\end{array}$ & - & $\begin{array}{l}\text { Raw material } \\
\text { contaminated }\end{array}$ & - & $\begin{array}{l}\text { Consecutive } \\
\text { workplaces in } \\
\text { relationship with } \\
\text { the working } \\
\text { process }\end{array}$ \\
\hline 36 & $\begin{array}{l}\text { Clinical } \\
\text { bronchiolitis } \\
\text { obliterans in } \\
\text { workers at a } \\
\text { microwave-popcorn } \\
\text { plant }\end{array}$ & $\begin{array}{l}\text { Workers involved } \\
\text { in mixing and } \\
\text { packaging tasks }\end{array}$ & $\begin{array}{l}\text { 2,3-butanedione } \\
\text { (flavor enhancer) }\end{array}$ & - & $\begin{array}{l}\text { Additives to raw } \\
\text { material }\end{array}$ & - & $\begin{array}{l}\text { Consecutive } \\
\text { workplaces in } \\
\text { relationship with } \\
\text { the working } \\
\text { process }\end{array}$ \\
\hline 37 & $\begin{array}{l}\text { An outbreak of } \\
\text { Pontiac fever due to } \\
\text { Legionella long beach } \\
\text { serogroup } 2 \text { found in } \\
\text { potting mix in a } \\
\text { horticultural nursery } \\
\text { in New Zealand }\end{array}$ & $\begin{array}{l}\text { Workers handling } \\
\text { contaminated } \\
\text { mulch }\end{array}$ & $\begin{array}{l}\text { Legionella long } \\
\text { beachae } \\
\text { serogroup }\end{array}$ & - & - & $\begin{array}{l}\text { Poor working } \\
\text { conditions }\end{array}$ & \\
\hline 38 & $\begin{array}{l}\text { Bacillus anthracis } \\
\text { contamination and } \\
\text { inhalational anthrax in } \\
\text { a mail processing and } \\
\text { distribution center }\end{array}$ & $\begin{array}{l}\text { Workers handling } \\
\text { envelopes or } \\
\text { involved in tasks of } \\
\text { postal classification }\end{array}$ & $\begin{array}{l}\text { Envelopes } \\
\text { containing } B . \\
\text { anthracis } \\
\text { spores }\end{array}$ & $\begin{array}{l}\text { Additional cases } \\
\text { due to an } \\
\text { environmental } \\
\text { spread of the } \\
\text { agent }\end{array}$ & - & - & $\begin{array}{l}\text { Consecutive } \\
\text { workplaces in } \\
\text { relationship with } \\
\text { the working } \\
\text { process }\end{array}$ \\
\hline 39 & $\begin{array}{l}\text { Airborne irritant contact } \\
\text { dermatitis and } \\
\text { conjunctivitis after } \\
\text { occupational exposure to } \\
\text { chlorothalonil in textiles. }\end{array}$ & $\begin{array}{l}\text { Workers involved in } \\
\text { cutting, Sewing, or } \\
\text { cleaning tent cloth }\end{array}$ & Chlorothalonil & - & $\begin{array}{l}\text { Raw material } \\
\text { contamination }\end{array}$ & - & - \\
\hline
\end{tabular}

(-) Non-reported. 
Table 5. Synthesis of outbreak information regarding to occupational relationships (IV).

\begin{tabular}{|c|c|c|c|c|c|c|c|}
\hline \multicolumn{8}{|c|}{ Information regarding to the occupational relationships } \\
\hline Ref. & Title & $\begin{array}{c}\text { Task } \\
\text { performed } \\
\text { (relationship } \\
\text { between cases) }\end{array}$ & $\begin{array}{l}\text { Agent/risk } \\
\text { exposure }\end{array}$ & $\begin{array}{c}\text { Environmental } \\
\text { spread }\end{array}$ & $\begin{array}{c}\text { Exposure } \\
\text { circumstances }\end{array}$ & $\begin{array}{l}\text { Concurrent } \\
\text { facts }\end{array}$ & $\begin{array}{l}\text { Cases } \\
\text { location }\end{array}$ \\
\hline 40 & $\begin{array}{l}\text { Q fever outbreak in } \\
\text { industrial setting. }\end{array}$ & $\begin{array}{l}\text { Office workers } \\
\text { and workers } \\
\text { setting on } \\
\text { non-protected } \\
\text { places }\end{array}$ & $\begin{array}{l}\text { Dust } \\
\text { containing } C \text {. } \\
\text { burnetii spores }\end{array}$ & $\begin{array}{l}\text { Additional } \\
\text { cases due to an } \\
\text { environmental } \\
\text { spread of the } \\
\text { agent }\end{array}$ & $\begin{array}{l}\text { Removing } \\
\text { contaminated } \\
\text { straw boards } \\
\text { from walls and } \\
\text { ceilings }\end{array}$ & $\begin{array}{l}\text { Office } \\
\text { renovation } \\
\text { works }\end{array}$ & $\begin{array}{l}\text { Areas } \\
\text { affected by } \\
\text { dust from } \\
\text { renovation } \\
\text { works }\end{array}$ \\
\hline 41 & $\begin{array}{l}\text { Case report: three } \\
\text { farmworkers who } \\
\text { gave birth to infants } \\
\text { with birth defects } \\
\text { closely grouped in } \\
\text { time and place- } \\
\text { Florida and North } \\
\text { Carolina, 2004-2005. }\end{array}$ & $\begin{array}{l}\text { Working in } \\
\text { tomato } \\
\text { grower's farms }\end{array}$ & $\begin{array}{l}\text { Exposure to } \\
\text { pesticides during } \\
\text { gestational period }\end{array}$ & - & - & $\begin{array}{l}\text { Poor } \\
\text { working } \\
\text { conditions. } \\
\text { Working in } \\
\text { violation of } \\
\text { the restricted } \\
\text { interval entry }\end{array}$ & $\begin{array}{l}\text { In grower } \\
\text { field }\end{array}$ \\
\hline 42 & $\begin{array}{l}\text { Clustered outbreak } \\
\text { of skin and eye } \\
\text { complaints among } \\
\text { catering staff. }\end{array}$ & Kitchen staff & UVC tubes & $\begin{array}{l}\text { Additional } \\
\text { cases due to an } \\
\text { environmental } \\
\text { spread of the } \\
\text { agent }\end{array}$ & $\begin{array}{l}\text { Electric fly } \\
\text { killers }\end{array}$ & $\begin{array}{l}\text { Incorrect } \\
\text { maintenance } \\
\text { (UVC tubes } \\
\text { into electric } \\
\text { fly traps) }\end{array}$ & $\begin{array}{l}\text { Working } \\
\text { areas next to } \\
\text { UVC tubes }\end{array}$ \\
\hline 43 & $\begin{array}{l}\text { A cluster of male } \\
\text { breast cancer in } \\
\text { office workers. }\end{array}$ & $\begin{array}{l}\text { Working office } \\
\text { next to an } \\
\text { electrical } \\
\text { switchgear } \\
\text { room }\end{array}$ & $\begin{array}{l}\text { Electric-magnetic } \\
\text { fields exposure }\end{array}$ & $\begin{array}{l}\text { Additional } \\
\text { cases due to an } \\
\text { environmental } \\
\text { spread of the } \\
\text { agent }\end{array}$ & $\begin{array}{l}\text { Electric } \\
\text { facilities in the } \\
\text { building }\end{array}$ & - & $\begin{array}{l}\text { Working } \\
\text { areas next to } \\
\text { electrical } \\
\text { switchgear } \\
\text { room }\end{array}$ \\
\hline
\end{tabular}

(-) Non-reported.

poor prevention practices were documented [41] [42].

This appraisal allows synthesising the occupational outbreaks variability in 4 standard pathways of occupational outbreaks, with the following characterisation for 3 epidemiological components: technological linkage, spatial distribution and agent involved.

SPOO Type I (Figure 2).

- Technological linkage: Workers share the development of a specific operation within the working process, and may also be involved in maintenance operations of installations or machinery.

- Spatial distribution: Cases are located in the area where the activity is carried out, although in outbreaks due to airborne substances, nearby cases may appear as a result of an environmental spread.

- Potentially involved agents: These may be materials, substances, products or sub-products, specifically used to perform a particular task.

SPOO Type II (Figure 3).

- Technological linkage: Workers are involved in different tasks or operations, 
N

S2

S3

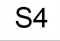

S5

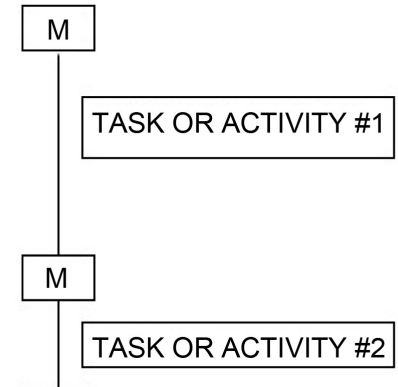

S6

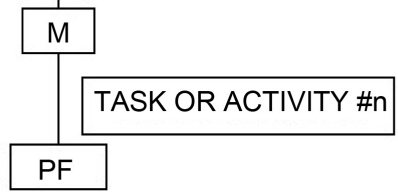

\begin{tabular}{|c|c|}
\hline$M$ & \multicolumn{2}{|c|}{ Raw material } \\
\hline S1 a S5 & Substances \\
\hline \hline PF & \multicolumn{2}{|c|}{ Final product } \\
\hline
\end{tabular}

\begin{tabular}{ll|} 
Mgent \\
$M$
\end{tabular}

Figure 2. Standard occupational outbreak pathway Type I.

Nisi

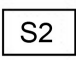

S3

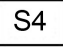

S5

N M s1

\section{$\mathrm{M}$}

TASK OR ACTIVITY \#1

$$
\mathrm{M}
$$

TASK OR ACTIVITY \#2

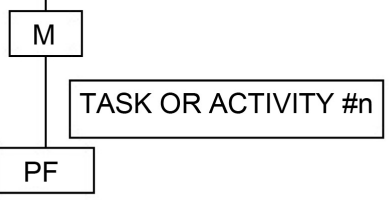

\begin{tabular}{|c|c|}
\hline$M$ & \multicolumn{2}{|c|}{ Raw material } \\
\hline S1 a S5 & Substances \\
\hline PF & \multicolumn{2}{|c|}{ Final product } \\
\hline
\end{tabular}

\begin{tabular}{ll|} 
Mgent \\
Cluster
\end{tabular}

Figure 3. Standard occupational outbreak pathway Type II.

no consecutive in the work sequence. A common exposure is identified due to the use of the same product, substance or technology.

- Spatial distribution: Cases are located in the different areas where tasks or operations requiring the use of the causal agent are carried out. In outbreaks due to airborne substances, nearby cases may appear as a result of an environmental spread.

- Potentially involved agents: These may be substances, products, sub-products 
or materials that are used at several points within the working process. Collective or individual protection equipment specifically used to perform those tasks may also be involved.

SPOO Type III (Figure 4).

- Technological linkage: Workers are involved in different consecutive tasks or operations within the working process.

- Spatial distribution: Cases are distributed throughout all or a part of the working process, according to the point where the causal agent appears. In outbreaks due to airborne substances, nearby cases may appear as a result of an environmental spread. The epidemic curve overlaps with the timing or sequence of the working process.

- Potentially involved agents: These may be the raw materials, substances or products which are incorporated into the raw material throughout the working process.

SPOO Type IV (Figure 5).

- Technological linkage: In this typology, the common exposure is due more to environmental than technological causes. The affected workers are related among themselves by sharing physical locations, rather than by the task performed or other technological reasons.

- Spatial distribution: Cases are located at specific places of the plant related to each other by architectural infrastructures, shared walls or places near to general equipment or facilities.

- Potentially involved agents: This epidemiological pathway stems from the spread of physical, chemical or biological contaminants from structural elements, walls, etc., emissions of contaminants from common workplace facilities or outdoor pollution.

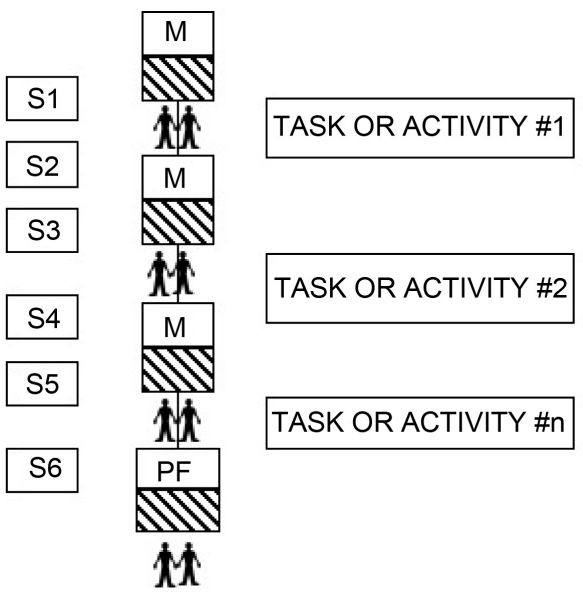

\begin{tabular}{|c|c|}
\hline$M$ & \multicolumn{2}{|c|}{ Raw material } \\
\hline S1 a S5 & Substances \\
\hline PF & \multicolumn{2}{|c|}{ Final product } \\
\hline
\end{tabular}

\begin{tabular}{ll|} 
Mgent \\
Cluster
\end{tabular}

Figure 4. Standard occupational outbreak pathway Type III. 


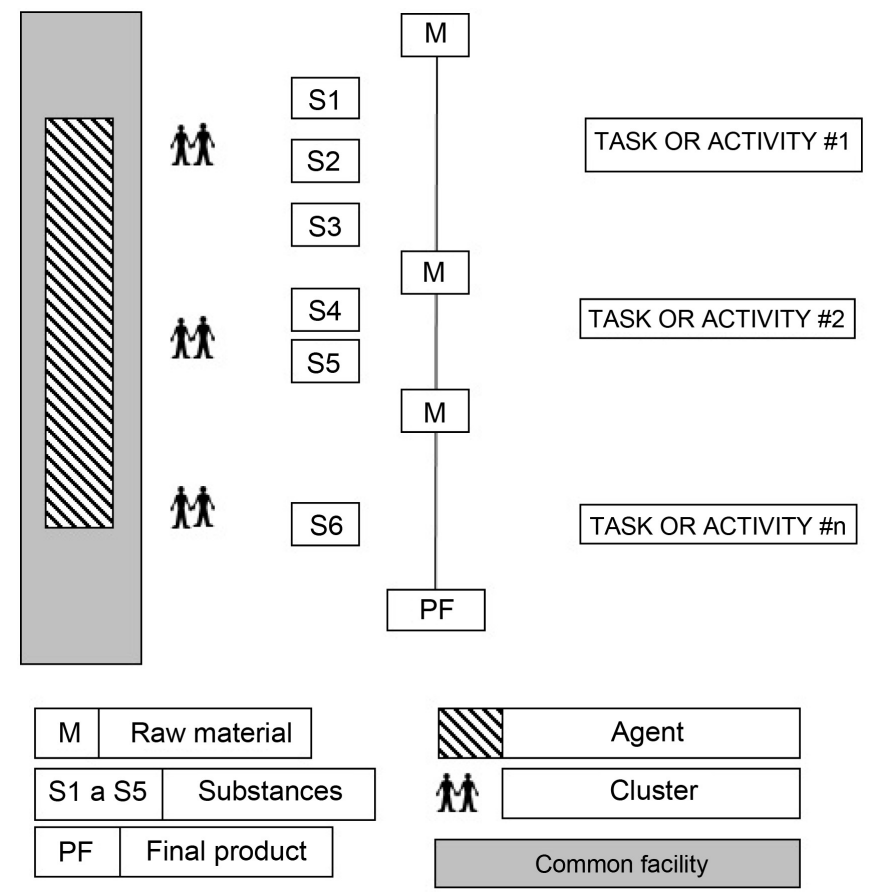

Figure 5. Standard occupational outbreak pathway Type IV.

\section{Model's Adequacy: Homogeneity and Concordance between Components for Each SPOO}

The analysis of 33 articles, used to formulate the theoretical SPOO (collection 1), and the 24 additional articles (collection 2) did not find any statistically significant differences as regards the probability of being classified in some one of the SPOO types (Table 6). There were no differences between the articles of collection 1 and 2 in order to be classified.

Out of the 57 outbreaks analysed, 53 (92.98\%) were allocated to one of the 4 SPOOs. Only 4 outbreaks did not meet the criteria to be allocated to one of them.

In order to consolidate the theoretical models, it is relevant to test the association and concordance between components for each pathway type.

For this analysis, a selection was carried out of 36 outbreaks documented in the three components under study.

(Table 7) shows a significant association between all three epidemiological components (technological linkage, spatial distribution and potentially involved agents) for each theoretical pathway type (Fisher's exact test $\mathrm{p}<0.001$ ).

The concordance analysed by the Kappa index shows no discordance among the three components of SPOO Type II (Kappa = 1). An almost perfect concordance was found among the components of SPOO Type IV

$\left(\mathrm{Kappa}_{\text {Technological linkage//Spatial distribution }}=0.93 ; \mathrm{Kappa}_{\text {Technological linkage/ } \mathrm{Agent} \text { involved }}=0.94\right.$; $\left.\mathrm{Kappa}_{\text {Spatial distribution/Agent involved }}=0.87\right)$.

For SPOO Type I (Table 7), the Kappa index showed an almost perfect concordance between technological link and spatial distribution 
Table 6. Difference in the level of allocation among the occupational outbreak collections under study.

\begin{tabular}{lccccc}
\hline & $\begin{array}{c}\text { Outbreaks } \\
\text { allocated due } \\
\text { to the } \\
\text { concordance } \\
\text { of } 3 \text { criteria }\end{array}$ & $\begin{array}{c}\text { Outbreaks } \\
\text { allocated due to } \\
\text { the concordance } \\
\text { of 2 criteria }\end{array}$ & $\begin{array}{c}\text { Not } \\
\text { allocated }\end{array}$ & Total & $\begin{array}{c}\text { Sig. F } \\
\text { (p) }\end{array}$ \\
\hline $\begin{array}{l}\text { Collection 1 } \\
\text { articles used to } \\
\text { formulate the } \\
\text { pathways of } \\
\text { occupational } \\
\text { outbreaks) }\end{array}$ & 18 & 14 & 1 & 33 & \\
$\begin{array}{l}\text { Collection 2 } \\
\text { additional collection }\end{array}$ & 13 & 8 & 3 & 24 & \\
\begin{tabular}{l} 
Total \\
\hline
\end{tabular} & 31 & 22 & 4 & 57 & \\
\hline
\end{tabular}

$\left(\mathrm{Kappa}_{\text {Technological linkage/Spatial distribution }}=0.94\right)$, a strong concordance between technological link and agent involved $\left(\mathrm{Kappa}_{\text {Technological linkage/Agent involved }}=0.66\right)$, showing a moderate concordance between spatial distribution and agent involved $\left(\mathrm{Kappa}_{\text {Spatial distribution/Agent involved }}=0.87\right)$.

There was a strong concordance among the components of SPOO Type III, between technological link and agent involved $\left(\mathrm{Kappa}_{\text {Technological linkage/Agent involved }}=\right.$ $0.68)$, as well as between spatial distribution and agent involved

$\left(\mathrm{Kappa}_{\text {Spatial distribution/Agent involved }}=0.68\right)$. No discordance was found between technological link and spatial distribution $\left(\right.$ Kappa $a_{\text {Technological linkage/Spatial distribution }}=1$ ) (Table 7).

A sub-sample of 36 outbreaks, fully documented in all three components, was analysed by calculating conditioned probability that allows to identify both the global behaviour of an outbreak and the behaviour of each component (Table 8).

Since the outbreak investigation started by getting to know the "Spatial distribution of cases", the most likely epidemiological scenarios are Type I ( $\mathrm{p}=$ $0.36)$ and Type IV $(\mathrm{p}=0.28)$.

Outbreaks classified as Type I showed a variability regarding the "Technological linkage". In spite of this, the most probable behaviour $(p=0.92)$ for this component was the one expected for that theoretical model.

Outbreaks classified according to their spatial distribution as Type II, Type III and Type IV showed, in its three components, a total concordance to the theoretical models.

Analysing the outbreak pathways by calculating variations with repetition of four elements (Type I, II, III and IV) taken in threes (technological linkage, spatial distribution and agent involved) make a total of 64 possible pathways.

The 36 outbreaks analysed (fully reported regarding the three components) show that, out of those 64 possible pathways, only 7 really happened (Table 9). 
Table 7. Homogeneity and concordance between components of the standard pathways of occupational outbreaks.

\begin{tabular}{|c|c|c|c|c|c|}
\hline \multirow[b]{2}{*}{ Components of analysed outbreaks } & \multicolumn{5}{|c|}{ Theoretical Outbreak pathway Type I } \\
\hline & $\begin{array}{c}\text { Spatial distribution } \\
\text { Type I }\end{array}$ & $\begin{array}{l}\text { Spatial distribution } \\
\text { Types II, III, IV }\end{array}$ & Total & $\begin{array}{l}\text { Sig. F } \\
(\mathrm{p})\end{array}$ & $\begin{array}{c}\text { Kappa } \\
\text { (p) }\end{array}$ \\
\hline Technological linkage Type I & 12 & 0 & 12 & & \\
\hline $\begin{array}{l}\text { Technological linkage } \\
\text { Types II, III, IV }\end{array}$ & 1 & 23 & 24 & $<0.001$ & 0.94 \\
\hline Total & 13 & 23 & 36 & & \\
\hline Components of analysed outbreaks & $\begin{array}{l}\text { Agent involved } \\
\text { Type I }\end{array}$ & $\begin{array}{l}\text { Agent involved } \\
\text { Types II, III, IV }\end{array}$ & Total & $\begin{array}{l}\text { Sig. F } \\
(\mathrm{p})\end{array}$ & $\begin{array}{c}\text { Kappa } \\
(\mathrm{p})\end{array}$ \\
\hline Technological linkage Type I & 7 & 5 & 12 & & \\
\hline $\begin{array}{l}\text { Technological linkage } \\
\text { Types II, III, IV }\end{array}$ & 0 & 24 & 24 & $<0.001$ & 0.66 \\
\hline Total & 7 & 29 & 36 & & \\
\hline Components of analysed outbreaks & $\begin{array}{l}\text { Agent involved } \\
\text { Type I }\end{array}$ & $\begin{array}{l}\text { Agent involved } \\
\text { Types II, III, IV }\end{array}$ & Total & $\begin{array}{l}\text { Sig. F } \\
(\mathrm{p})\end{array}$ & $\begin{array}{c}\text { Kappa } \\
(\mathrm{p})\end{array}$ \\
\hline Spatial distribution Type I & 7 & 6 & 13 & & \\
\hline Spatial distribution Type II, III, IV & 0 & 23 & 23 & $<0.001$ & 0.60 \\
\hline Total & 7 & 29 & 36 & & \\
\hline \multirow[b]{2}{*}{ Components of analysed outbreaks } & \multicolumn{5}{|c|}{ Theoretical Outbreak pathway Type II } \\
\hline & $\begin{array}{c}\text { Spatial distribution } \\
\text { Type II }\end{array}$ & $\begin{array}{l}\text { Spatial distribution } \\
\text { Types I, III, IV }\end{array}$ & Total & $\begin{array}{l}\text { Sig. F } \\
(\mathrm{p})\end{array}$ & $\begin{array}{c}\text { Kappa } \\
(\mathrm{p})\end{array}$ \\
\hline Technological linkage Type II & 7 & 0 & 7 & & \\
\hline $\begin{array}{l}\text { Technological linkage } \\
\text { Types I, III, IV }\end{array}$ & 0 & 29 & 29 & $<0.001$ & 1 \\
\hline Total & 7 & 29 & 36 & & \\
\hline Components of analysed outbreaks & $\begin{array}{l}\text { Agent involved } \\
\text { Type II }\end{array}$ & $\begin{array}{l}\text { Agent involved } \\
\text { Types I, III, IV }\end{array}$ & Total & $\begin{array}{l}\text { Sig. F } \\
(\mathrm{p})\end{array}$ & $\begin{array}{c}\text { Kappa } \\
(\mathrm{p})\end{array}$ \\
\hline Technological linkage Type II & 7 & 0 & 7 & & \\
\hline $\begin{array}{l}\text { Technological linkage } \\
\text { Types I, III, IV }\end{array}$ & 0 & 29 & 29 & $<0.001$ & 1 \\
\hline Total & 7 & 29 & 36 & & \\
\hline Components of analysed outbreaks & $\begin{array}{c}\text { Agent involved } \\
\text { Type II }\end{array}$ & $\begin{array}{l}\text { Agent involved } \\
\text { Types I, III, IV }\end{array}$ & Total & $\begin{array}{l}\text { Sig. F } \\
(\mathrm{p})\end{array}$ & $\begin{array}{c}\text { Kappa } \\
(\mathrm{p})\end{array}$ \\
\hline Spatial distribution Type II & 7 & 0 & 7 & & \\
\hline Spatial distribution Types I, III, IV & 0 & 29 & 29 & $<0.001$ & 1 \\
\hline Total & 7 & 29 & 36 & & \\
\hline \multirow[b]{2}{*}{ Components of analysed outbreaks } & \multicolumn{5}{|c|}{ Theoretical Outbreak pathway Type III } \\
\hline & $\begin{array}{c}\text { Spatial distribution } \\
\text { Type III }\end{array}$ & $\begin{array}{l}\text { Spatial distribution } \\
\text { Types I, II, IV }\end{array}$ & Total & $\begin{array}{l}\text { Sig. F } \\
(\mathrm{p})\end{array}$ & $\begin{array}{c}\text { Kappa } \\
(\mathrm{p})\end{array}$ \\
\hline
\end{tabular}




\section{Continued}

\begin{tabular}{|c|c|c|c|c|c|}
\hline Technological linkage Type III & 6 & 0 & 6 & & \\
\hline $\begin{array}{l}\text { Technological linkage } \\
\text { Types I, II, IV }\end{array}$ & 0 & 30 & 30 & $<0.001$ & 1 \\
\hline Total & 6 & 30 & 36 & & \\
\hline Components of analysed outbreaks & $\begin{array}{l}\text { Agent involved } \\
\text { Type III }\end{array}$ & $\begin{array}{l}\text { Agent involved } \\
\text { Types I, II, IV }\end{array}$ & Total & $\begin{array}{l}\text { Sig. F } \\
\text { (p) }\end{array}$ & $\begin{array}{l}\text { Kappa } \\
(\mathrm{p})\end{array}$ \\
\hline Technological linkage Type III & 6 & 0 & 6 & & \\
\hline $\begin{array}{l}\text { Technological linkage } \\
\text { Types I, II, IV }\end{array}$ & 4 & 26 & 30 & $<0.001$ & 0.68 \\
\hline Total & 10 & 26 & 36 & & \\
\hline Components of analysed outbreaks & $\begin{array}{l}\text { Agent involved } \\
\text { Type III }\end{array}$ & $\begin{array}{l}\text { Agent involved } \\
\text { Types I, II, IV }\end{array}$ & Total & $\begin{array}{l}\text { Sig. F } \\
(\mathrm{p})\end{array}$ & $\begin{array}{l}\text { Kappa } \\
\text { (p) }\end{array}$ \\
\hline Spatial distribution Type III & 6 & 0 & 6 & & \\
\hline Spatial distribution Types I, II, IV & 4 & 26 & 30 & $<0.001$ & 0.68 \\
\hline Total & 10 & 26 & 36 & & \\
\hline \multirow[b]{2}{*}{ Components of analysed outbreaks } & \multicolumn{5}{|c|}{ Theoretical Outbreak pathway Type IV } \\
\hline & $\begin{array}{c}\text { Spatial distribution } \\
\text { Type IV }\end{array}$ & $\begin{array}{c}\text { Spatial distribution } \\
\text { Types I, II, III }\end{array}$ & Total & $\begin{array}{l}\text { Sig. F } \\
\text { (p) }\end{array}$ & $\begin{array}{c}\text { Kappa } \\
(\mathrm{p})\end{array}$ \\
\hline Technological linkage Type IV & 10 & 1 & 11 & & \\
\hline $\begin{array}{l}\text { Technological linkage } \\
\text { Types I, II, III }\end{array}$ & 0 & 25 & 25 & $<0.001$ & 0.93 \\
\hline Total & 10 & 26 & 36 & & \\
\hline Components of analysed outbreaks & $\begin{array}{l}\text { Agent involved } \\
\text { Type IV }\end{array}$ & $\begin{array}{l}\text { Agent involved } \\
\text { Types I, II, III }\end{array}$ & Total & $\begin{array}{l}\text { Sig. F } \\
(\mathrm{p})\end{array}$ & $\begin{array}{l}\text { Kappa } \\
\text { (p) }\end{array}$ \\
\hline Technological linkage Type IV & 11 & 0 & 11 & & \\
\hline $\begin{array}{l}\text { Technological linkage } \\
\text { Types I, II, III }\end{array}$ & 1 & 24 & 25 & $<0.001$ & 0.94 \\
\hline Total & 12 & 24 & 36 & & \\
\hline Components of analysed outbreaks & $\begin{array}{l}\text { Agent involved } \\
\text { Type IV }\end{array}$ & $\begin{array}{l}\text { Agent involved } \\
\text { Types I, II, III }\end{array}$ & Total & $\begin{array}{l}\text { Sig. F } \\
\text { (p) }\end{array}$ & $\begin{array}{l}\text { Kappa } \\
(\mathrm{p})\end{array}$ \\
\hline Spatial distribution Type IV & 10 & 0 & 10 & & \\
\hline Spatial distribution Types I, II, III & 2 & 24 & 26 & $<0.001$ & 0.87 \\
\hline Total & 12 & 24 & 36 & & \\
\hline
\end{tabular}

Source: 36 outbreaks, fully documented in all three components under study. 
Table 8. Probability of occupational outbreak pathway. The investigation starts by analysing the spatial distribution of cases.

\begin{tabular}{ccc}
\hline \multicolumn{3}{c}{ Outbreak components } \\
\cline { 2 - 4 } Spatial distribution $(\mathrm{p} / \mathrm{n})$ & $\begin{array}{c}\text { Technological linkage } \\
(\mathrm{p} / \mathrm{n})\end{array}$ & $\begin{array}{c}\text { Agent involved } \\
(\mathrm{p} / \mathrm{n})\end{array}$ \\
\hline & & Type I $(\mathrm{p}=0.58 / \mathrm{n}=7)$ \\
Type I $(\mathrm{p}=0.36 / \mathrm{n}=13)$ & Type I $(\mathrm{p}=0.92 / \mathrm{n}=12)$ & Type III $(\mathrm{p}=0.33 / \mathrm{n}=4)$ \\
& & Type IV $(\mathrm{p}=0.08 / \mathrm{n}=1)$ \\
OUTBREAK & Type IV $(\mathrm{p}=0.08 / \mathrm{n}=1)$ & Type IV $(\mathrm{p}=1.00 / \mathrm{n}=1)$ \\
Type III $(\mathrm{p}=0.17 / \mathrm{n}=6)$ & Type III $(\mathrm{p}=1.00 / \mathrm{n}=6)$ & Type III $(\mathrm{p}=1.00 / \mathrm{n}=6)$ \\
Type IV $(\mathrm{p}=0.28 / \mathrm{n}=10)$ & Type IV $(\mathrm{p}=1.00 / \mathrm{n}=10)$ & Type IV $(\mathrm{p}=1.00 / \mathrm{n}=10)$ \\
\hline
\end{tabular}

Source: 36 outbreaks, fully documented in all three components under study.

Table 9. Pathways of occupational outbreak: occurrence probabilities.

\begin{tabular}{ccccc}
\hline & \multicolumn{2}{c}{ Standard pathways: occurrence probabilities } & & \\
& & & \\
Spatial distribution & Technological linkage & Agent involved & 0.28 & \\
\hline Type IV & Type IV & Type IV & 0.19 & \multirow{2}{*}{0.83} \\
Type II & Type II & Type II & 0.19 & \\
Type I & Type I & Type I & 0.17 & \\
Type III & Type III & Type III & & \\
& Not-standard pathways: occurrence probabilities & & \\
Type I & Type I & Type III & 0.11 & \\
Type I & Type I & Type IV & 0.03 & 0.17 \\
Type I & Type IV & Type IV & 0.03 & \\
\hline
\end{tabular}

Source: 36 outbreaks, fully documented in all three components under study.

The most probable ones were those which behaved exactly like the model (83\%).

\section{Discussion}

The investigation of an occupational outbreak, once the index case has been identified, triggers a stress situation between the company's social agents, who exert great pressure on epidemiologists. This fact, together with the variability of the possible causes, makes the first steps to investigate the outbreak particularly difficult. The lack of knowledge about the working process, the social climate, the disorientation and the uncertainty stress the field epidemiologist.

Occupational epidemiology shows differential facts inherent to the work environment. Exposure to risk at the workplace is generally known. But a situation which is not common in public health epidemiology and which needs a new element is "the technology used in working processes". This element causes an exposure which varies according to the working process or work sequence, in such a way that the epidemic curve depends on the tasks performed at each 
moment of the work process or sequence and produces a differentiable epidemiologic behaviour.

In this sense, a critical and in-depth evaluation of the 33 occupational outbreaks reported in scientific journals and the analysis of three parameters epidemiologically similar (link between cases and working process, spatial distribution and exposure to agents or risks involved), allows to corroborate the hypothesis that the variability of occupational outbreaks can be normalised in four standard pathways (Types I, II, III and IV) where a differential and proper epidemiological behaviour has been demonstrated regarding the link with the working process, the distribution of cases and the potentially involved agents.

Results are also conclusive as regards approaching the study of epidemic outbreaks in work environments on the basis of the distribution of cases within the company. This aspect is decisive in behaviours of Types II, III and IV.

Results are also conclusive as regards the best way to approach the investigation of an epidemic outbreak in the work environment. The early awareness of cases distribution within a company is an epidemiological dimension that is vital to identify the suspected causal agent, mainly in pathways Types II, III and IV.

The most frequent epidemiological pathway in occupational outbreaks is Type I. This means outbreaks that affect workers who perform together a specific task within the working process, located in the area where the activity is carried out and caused by materials, substances, products or by-products used specifically to perform a particular task. And also Type IV, which means outbreaks which are more due to environmental than technological causes. Their origin is linked to the spread of physical, chemical or biological pollutants from structural elements or common work facilities.

It was impossible to assign a typology in 4 outbreaks, either because the publication did not provide information on two or more components [41] [44] [45] or because at least two components showed a behaviour different from the expected one according to the theoretical pathway [46].

The analysis of the 36 outbreaks that are fully documented regarding the three components (technological linkage, spatial distribution and agent involved) has shown their epidemiological trajectory. The probability that a given outbreak would fit its three components into any of the four theoretical pathways was 0.83 .

The outbreaks classified as Type II, III and IV show a full concordance with the theoretical itinerary.

\section{Conclusion}

The results corroborate the hypothesis where the occupational outbreaks present a limited variability, allowing them to be categorized into a theoretical model of 4 standard occupational outbreak pathways. The incorporation of those pathways to the field of occupational epidemiology will allow, just by being allocated to one of them: 1) to provide early guidance to epidemiological, clinical and en- 
vironmental studies focused on the specific hypothesis of causality; 2) to anticipate preventive measures and 3) to contribute to an earlier and more efficient outbreak resolution.

\section{Acknowledgements}

We acknowledge Cristina Fernandez Nebreda (sworn Translator of English and French, former Translator at the European Union) for her advice in the review, translation and linguistic revision of the manuscript.

\section{Conflicts of Interest}

The authors declare no conflicts of interest regarding the publication of this paper.

\section{References}

[1] Ramazzini, B. (2007) Tratado de las Enfermedades de los Artesanos. 3th Edition, Instituto de Salud Carlos III, Madrid.

[2] Corfiati, M., Scarselli, A., Binazzi, A., Di Marzio, D., Verardo, M., Mirabelli, D., et al. (2015) Epidemiological Patterns of Asbestos Exposure and Spatial Clusters of Incident Cases of Malignant Mesothelioma from the Italian National Registry. BMC Cancer, 15, Article No. 286. https://doi.org/10.1186/s12885-015-1301-2

[3] European Centre for Disease Prevention and Control (2019) Field Epidemiology Manual. https://wiki.ecdc.europa.eu/fem/Site\%20Pages/Home.aspx

[4] Centers for Disease Control (2016) Principles of Epidemiology in Public Health Practice: An Introduction to Applied Epidemiology and Biostatistics. https://www.cdc.gov/csels/dsepd/ss1978/lesson6/section2.html

[5] National Health and Medical Research (2019) Australian Guidelines for the Prevention and Control of Infection in Healthcare. https://www.nhmrc.gov.au/about-us/publications/australian-guidelines-preventionand-control-infection-healthcare-2019

[6] Hernberg, S. (1994) New Epidemics in Occupational Health. Scandinavian Journal of Work, Environment \& Health, 20, 309-311. https://doi.org/10.5271/sjweh.1392

[7] Schulte, P.A., Ehrenberg, R.L. and Singal, M. (1987) Investigation of Occupational Cancer Clusters: Theory and Practice. American Journal of Public Health, 77, 52-56. https://doi.org/10.2105/AJPH.77.1.52

[8] Castellano Arroyo, M. (2014) Reivindicando a Ramazzini, siempre de actualidad. Medicina y Seguridad del Trabajo, 60, 14-15. https://doi.org/10.4321/S0465-546X2014000600002

[9] Moya, C., Newman, A.J. and Ant, J.M. (1994) Outbreak of Organising Pneumonia in Textile Printing Sprayers. Lancet, 344, 498-502. https://doi.org/10.1016/S0140-6736(94)91896-1

[10] Zimmermann, M., Abraira, L., Hervada, S., Maqueda, J. and Martínez, J.F. (2005) Brote epidémico tóxico ocurrido en población trabajadora de una industria textil de Redondela (Pontevedra). Medicina y Seguridad del Trabajo, 51, 55-61.

[11] Thyssen, J.P., Sederberg-Olsen, N., Thomsen, J.F. and Menné, T. (2006) Contact Dermatitis from Methylisothiazolinone in a Paint Factory. Contact Dermatitis, 54, 322-324. https://doi.org/10.1111/j.0105-1873.2006.00850.x 
[12] Kiec-Swierczynska, M., Krecisz, B., Swierczynska-Machura, D. and Zaremba, J. (2005) An Epidemic of Occupational Contact Dermatitis from an Acrylic Glue. Contact Dermatitis, 52, 121-125. https://doi.org/10.1111/j.0105-1873.2005.00527.x

[13] Chu, C.Y., Pontén, A., Sun, C.C. and Jee, S.H. (2006) Concomitant Contact Allergy to the Resins, Reactive Diluents and Hardener of a Bisphenol A/F-Based Epoxy Resin in Subway Construction Workers. Contact Dermatitis, 54, 131-139. https://doi.org/10.1111/j.0105-1873.2006.00806.x

[14] Frick, M., Björkner, B., Hamnerius, N. and Zimerson, E. (2003) Allergic Contact Dermatitis from Dicyclohexylmethane-4,4'-diisocyanate. Contact Dermatitis, 48, 305-309. https://doi.org/10.1034/j.1600-0536.2003.00123.x

[15] Frick, M., Isaksson, M., Björkner, B., Hindsén, M., Pontén, A. and Bruze, M. (2003) Occupational Allergic Contact Dermatitis in a Company Manufacturing Boards Coated with Isocyanate Lacquer. Contact Dermatitis, 48, 255-260.

https://doi.org/10.1034/j.1600-0536.2003.00107.x

[16] Hnizdo, E., Sylvain, D., Lewis, D.M., Pechter, E. and Kreiss, K. (2004) New-Onset Asthma Associated with Exposure to 3-amino-5-mercapto-1,2,4-triazole. Journal of Occupational and Environmental Medicine, 46, 1246-1252.

[17] Holzbauer, S.M., De Vries, A.S., Sejvar, J.J., Lees, C.H., Adjemian, J., McQuiston, J.H., et al. (2010) Epidemiologic Investigation of Immune-Mediated Polyradiculoneuropathy among Abattoir Workers Exposed to Porcine Brain. PLoS ONE, 5, e9782. https://doi.org/10.1371/journal.pone.0009782

[18] Gash, D.M., Rutland, K., Hudson, N.L., Sullivan, P.G., Bing, G., Cass, W.A., et al. (2008) Trichloroethylene: Parkinsonism and Complex 1 Mitochondrial Neurotoxicity. Annals of Neurology, 63, 184-192. https://doi.org/10.1002/ana.21288

[19] Linz, A.J., Greenham, R.K. and Fallon Jr., L.F. (2006) Methemoglobinemia: An Industrial Outbreak among Rubber Molding Workers. Journal of Occupational and Environmental Medicine, 48, 523-528. https://doi.org/10.1097/01.jom.0000201815.32098.99

[20] Tague, I., Llewellin, P., Burton, K., Buchan, R. and Yates, D.H. (2004) Cold Blast Furnace Syndrome: A New Source of Toxic Inhalation by Nitrogen Oxides. Occupational and Environmental Medicine, 61, 461-463. https://doi.org/10.1136/oem.2002.005686

[21] Washko, R.M., Day, B., Parker, J.E., Castellan, R.M. and Kreiss, K. (2000) Epidemiologic Investigation of Respiratory Morbidity at a Nylon Flock Plant. American Journal of Industrial Medicine, 38, 628-638. https://doi.org/10.1002/1097-0274(200012)38:6\%3C628::AID-AJIM3\%3E3.0.CO;2$\underline{\mathrm{U}}$

[22] Akgun, M., Araz, O., Akkurt, I., Eroglu, A., Alper, F., Saglam, L., et al. (2008) An Epidemic of Silicosis among Former Denim Sandblasters. European Respiratory Journal, 32, 1295-1303. https://doi.org/10.1183/09031936.00093507

[23] Humphreys, C.P., Morgan, S.J., Walapu, M., Harrison, G.A., Keen, A.P., Efstratiou, A., et al. (2007) Group A Streptococcal Skin Infection Outbreak in an Abattoir: Lessons for Prevention. Epidemiology \& Infection, 135, 321-327. https://doi.org/10.1017/S0950268806006819

[24] Hodgson, M.J., Bracker, A., Yang, C., Storey, E., Jarvis, B.J., Milton, D., et al. (2001) Hypersensitivity Pneumonitis in a Metal-Working Environment. American Journal of Industrial Medicine, 39, 616-628. https://doi.org/10.1002/ajim.1061

[25] Dawkins, P., Robertson, A., Robertson, W., Moore, V., Reynolds, J., Langman, G., et al. (2006) An Outbreak of Extrinsic Alveolitis at a Car Engine Plant. Occupational 
Medicine, 56, 559-565. https://doi.org/10.1093/occmed/kql110

[26] Foo, C.C., Goon, A.T., Leow, Y.H. and Goh, C.L. (2006) Adverse Skin Reactions to Personal Protective Equipment against Severe Acute Respiratory Syndrome-A Descriptive Study in Singapore. Contact Dermatitis, 55, 291-294. https://doi.org/10.1111/j.1600-0536.2006.00953.x

[27] Gupta, A. and Rosenman, K.D. (2006) Hypersensitivity Pneumonitis Due to Metal Working Fluids: Sporadic or under Reported? American Journal of Industrial Medicine, 49, 423-433. https://doi.org/10.1002/ajim.20312

[28] O’Brien, D.M. (2003) Aerosol Mapping of a Facility with Multiple Cases of Hypersensitivity Pneumonitis: Demonstration of Mist Reduction and a Possible Dose/ Response Relationship. Applied Occupational and Environmental Hygiene, 18, 947-952. https://doi.org/10.1080/10473220390237656

[29] Mota, F., Silva, E., Varela, P., Azenha, A. and Massa, A. (2000) An Outbreak of Occupational Textile Dye Dermatitis from Disperse Blue 106. Contact Dermatitis, 43, 235-237.

[30] Robertson, W., Robertson, A.S., Burge, C.B., Moore, V.C., Jaakkola, M.S., Dawkins, P.A., et al. (2007) Clinical Investigation of an Outbreak of Alveolitis and Asthma in a Car Engine Manufacturing Plant. Thorax, 62, 981-990. https://doi.org/10.1136/thx.2006.072199

[31] Walters, G.I., Moore, V.C., Robertson, A.S., Burge, C.B., Vellore, A.D. and Burge, P.S. (2012) An Outbreak of Occupational Asthma Due to Chromium and Cobalt. Occupational Medicine, 62, 533-540. https://doi.org/10.1093/occmed/kqs111

[32] Cullinan, P., Harris, J.M., Newman Taylor, A.J., Hole, A.M., Jones, M., Barnes, F., et al. (2000) An Outbreak of Asthma in a Modern Detergent Factory. Lancet, 356, 1899-1900. https://doi.org/10.1016/S0140-6736(00)03264-5

[33] Madsen, A.M., Tendal, K., Schlünssen, V. and Heltberg, I. (2012) Organic Dust Toxic Syndrome at a Grass Seed Plant Caused by Exposure to High Concentrations of Bioaerosols. Annals of Occupational Hygiene, 56, 776-788.

[34] Boehmer, T.K., Jones, T.S., Ghosh, T.S., McCammon, C.S. and Vogt, R.L. (2009) Cluster of Presumed Organic Dust Toxic Syndrome Cases among Urban Landscape Workers-Colorado, 2007. American Journal of Industrial Medicine, 52, 534-538. https://doi.org/10.1002/ajim.20699

[35] Terry, J., Trent, M. and Bartlett, M. (2000) A Cluster of Leptospirosis among Abattoir Workers. Communicable Diseases Intelligence, 24, 158-160.

[36] Kreiss, K., Gomaa, A., Kullman, G., Fedan, K., Simoes, E.J. and Enright, P.L. (2002) Clinical Bronchiolitis Obliterans in Workers at a Microwave-Popcorn Plant. New England Journal of Medicine, 347, 330-338. https://doi.org/10.1056/NEJMoa020300

[37] Cramp, G.J., Harte, D., Douglas, N.M., Graham, F., Schousboe, M. and Sykes, K. (2010) An Outbreak of Pontiac Fever Due to Legionella longbeachae Serogroup 2 Found in Potting Mix in a Horticultural Nursery in New Zealand. Epidemiology \& Infection, 138, 15-20. https://doi.org/10.1017/S0950268809990835

[38] Sanderson, W.T., Stoddard, R.R., Echt, A.S., Piacitelli, C., Kim, D., et al. (2004) Bacillus anthracis Contamination and Inhalational Anthrax in a Mail Processing and Distribution Center. Journal of Applied Microbiology, 96, 1048-1056.

https://doi.org/10.1111/j.1365-2672.2004.02223.x

[39] Lensen, G., Jungbauer, F., Gonçalo, M. and Coenraads, P.J. (2007) Airborne Irritant Contact Dermatitis and Conjunctivitis after Occupational Exposure to Chlorothalonil in Textiles. Contact Dermatitis, 57, 181-186. https://doi.org/10.1111/j.1600-0536.2007.01196.x 
[40] van Woerden, H.C., Mason, B.W., Nehaul, L.K., Smith, R., Salmon, R.L., Healy, B., et al. (2004) Q Fever Outbreak in Industrial Setting. Emerging Infectious Diseases, 10, 1282-1289. https://doi.org/10.3201/eid1007.030536

[41] Calvert, G.M., Alarcon, W.A., Chelminski, A., Crowley, M.S., Barrett, R., Correa, A., et al. (2007) Case Report: Three Farmworkers Who Gave Birth to Infants with Birth Defects Closely Grouped in Time and Place-Florida and North Carolina, 2004-2005. Environmental Health Perspectives, 115, 787-791.https://doi.org/10.1289/ehp.9647

[42] Oliver, H., Moseley, H., Ferguson, J. and Forsyth, A. (2005) Clustered Outbreak of Skin and Eye Complaints among Catering Staff. Occupational Medicine, 55, 149-153. https://doi.org/10.1093/occmed/kqi021

[43] Milham, S. (2004) A Cluster of Male Breast Cancer in Office Workers. American Journal of Industrial Medicine, 46, 86-87. https://doi.org/10.1002/ajim.20027

[44] Anderson, S.E., Tapp, L., Durgam, S., Meade, B.J., Jackson, L.G. and Cohen, D.E. (2012) The Identification of a Sensitizing Component Used in the Manufacturing of an Ink Ribbon. Journal of Immunotoxicology, 9, 193-200. https://doi.org/10.3109/1547691X.2011.654364

[45] Shaw, I. (2010) Motor Neurone Disease-A Methyl Bromide Exposure Cluster Points to a Causal Mechanism. Human \& Experimental Toxicology, 29, 241-242. https://doi.org/10.1177/0960327109359462

[46] Kar-Purkayastha, I., Balasegaram, S., Sen, D., Rehman, A.J., Dargan, P.I., Johnston, D., et al. (2012) Lead: Ongoing Public and Occupational Health Issues in Vulnerable Populations: A Case Study. Journal of Public Health, 34, 176-182.

https://doi.org/10.1093/pubmed/fdr077 